\title{
Flu Matrix Peptide p58-66
}

National Cancer Institute

\section{Source}

National Cancer Institute. Flu Matrix Peptide p58-66. NCI Thesaurus. Code C39677.

A short chain synthetic antig enic peptide (GILGFVFT L) derived from the influenza virus A matrix protein and presented by HLA-A2 major histocompatibility complex (MHC) class I molecules. Flu matrix peptide p58-66 stimulates the lytic functions of cytotoxic $T$ lymphocytes (CT Ls), which may result in the eradication of virus-infected or malignant tumor cells. 